\title{
Front Matter: Volume 9714
}

, "Front Matter: Volume 9714," Proc. SPIE 9714, Single Molecule Spectroscopy and Superresolution Imaging IX, 97141G (24 June 2016); doi: 10.1117/12.2239743

SPIE. Event: SPIE BiOS, 2016, San Francisco, California, United States 


\title{
Single Molecule Spectroscopy and Superresolution Imaging IX
}

\author{
Jörg Enderlein \\ Ingo Gregor \\ Zygmunt Karol Gryczynski \\ Rainer Erdmann \\ Felix Koberling \\ Editors
}

13-14 February 2016

San Francisco, California, United States

Sponsored by

SPIE

Cosponsored by

PicoQuant GmbH (Germany)

Published by

SPIE 
The papers in this volume were part of the technical conference cited on the cover and title page. Papers were selected and subject to review by the editors and conference program committee. Some conference presentations may not be available for publication. Additional papers and presentation recordings may be available online in the SPIE Digital Library at SPIEDigitallibrary.org.

The papers reflect the work and thoughts of the authors and are published herein as submitted. The publisher is not responsible for the validity of the information or for any outcomes resulting from reliance thereon.

Please use the following format to cite material from these proceedings:

Author(s), "Title of Paper," in Single Molecule Spectroscopy and Superresolution Imaging IX, edited by Jörg Enderlein, Ingo Gregor, Zygmunt K. Gryczynski, Rainer Erdmann, Felix Koberling, Proceedings of SPIE Vol. 9714 (SPIE, Bellingham, WA, 2016) Six-digit Article CID Number.

ISSN: 1605-7422

ISSN: 2410-9045 (electronic)

ISBN: 9781628419481

Published by

SPIE

P.O. Box 10, Bellingham, Washington 98227-0010 USA

Telephone +1 3606763290 (Pacific Time) · Fax + 13606471445

SPIE.org

Copyright (C) 2016, Society of Photo-Optical Instrumentation Engineers.

Copying of material in this book for internal or personal use, or for the internal or personal use of specific clients, beyond the fair use provisions granted by the U.S. Copyright Law is authorized by SPIE subject to payment of copying fees. The Transactional Reporting Service base fee for this volume is $\$ 18.00$ per article (or portion thereof), which should be paid directly to the Copyright Clearance Center (CCC), 222 Rosewood Drive, Danvers, MA 01923. Payment may also be made electronically through CCC Online at copyright.com. Other copying for republication, resale, advertising or promotion, or any form of systematic or multiple reproduction of any material in this book is prohibited except with permission in writing from the publisher. The CCC fee code is $1605-7422 / 16 / \$ 18.00$.

Printed in the United States of America.

Publication of record for individual papers is online in the SPIE Digital Library.

\section{SPIE. DIGITAL}

SPIEDigitalLibrary.org

Paper Numbering: Proceedings of SPIE follow an e-First publication model. A unique citation identifier (CID) number is assigned to each article at the time of publication. Utilization of CIDs allows articles to be fully citable as soon as they are published online, and connects the same identifier to all online and print versions of the publication. SPIE uses a six-digit CID article numbering system structured as follows:

- The first four digits correspond to the SPIE volume number.

- The last two digits indicate publication order within the volume using a Base 36 numbering

system employing both numerals and letters. These two-number sets start with 00, 01, 02, 03, 04, 05, 06, 07, 08, 09, OA, OB ... 0Z, followed by 10-1Z, 20-2Z, etc. The CID Number appears on each page of the manuscript. 


\title{
Contents
}

\author{
$\checkmark$ Authors \\ vii Conference Committee
}

\section{FLIM, FRET AND FCS I}

971401 Heterogeneity and restricted state selection in FRET with fluorescent proteins [9714-1]

971402 Optimized green fluorescent protein fused to $F_{0} F_{1}$-ATP synthase for single-molecule FRET using a fast anti-Brownian electrokinetic trap [9714-2]

\section{FLIM, FRET AND FCS II}

971405 Photon-HDF5: open data format and computational tools for timestamp-based single-molecule experiments [9714-5]

971406 Analyzing blinking effects in super resolution localization microscopy with single-photon SPAD imagers (PicoQuant Young Investigator Award) [9714-6]

\section{BIOLOGICAL APPLICATIONS OF SINGLE MOLECULE DETECTION TECHNIQUES}

9714 OA Photophysics in single light-harvesting complexes II: from micelle to native nanodisks [9714-10]

$9714 \mathrm{OB}$ Observing single $\mathrm{F}_{\mathrm{O}} \mathrm{F}_{1}$-ATP synthase at work using an improved fluorescent protein mNeonGreen as FRET donor [9714-11]

\section{NANOSCOPY AND SUPERRESOLUTION MICROSCOPY I}

9714 OF Multi-pulse pumping for far-field super-resolution imaging [9714-15]

9714 OG Fast and precise 3D fluorophore localization by gradient fitting [9714-17]

\section{NEW DEVELOPMENTS IN METHODS AND SYSTEMS I}

$9714 \mathrm{OH} \quad$ Generating 3D depletion distribution in an achromatic single-channel monolithic system [9714-18]

9714 Ol Nanopore integrated with Au clusters formed under electron beam irradiation for single molecule analysis [9714-19] 
$97140 \mathrm{~J}$ Custom field-of-view quantitative label-free microscopy by optofluidic space-time digital holography [9714-20]

NANOSCOPY AND SUPERRESOLUTION MICROSCOPY III

9714 OT Correlating structure and fluorescence dynamics of quantum dot clusters using super-resolution imaging [9714-30]

POSTER SESSION

971410 Super-resolved image acquisition with full-field localization-based microscopy: theoretical analysis and evaluation [9714-36]

971411 Conventional fluorescence microscopy below the diffraction limit with simultaneous capture of two fluorophores in DNA origami [9714-37]

971414 Accurate axial localization by conical diffraction beam shaping generating a dark-helix PSF [9714-40]

971419 Novel plasmonic platform for ultra-sensitive detection and diagnostics [9714-45] 


\section{Authors}

Numbers in the index correspond to the last two digits of the six-digit citation identifier (CID) article numbering system used in Proceedings of SPIE. The first four digits reflect the volume number. Base 36 numbering is employed for the last two digits and indicates the order of articles within the volume. Numbers start with 00, 01, 02, 03, 04, 05, 06, 07, 08, 09, 0A, 0B...0Z, followed by 10-1Z, 20-2Z, etc.

Antolovic, Ivan Michel, 06

Bain, A. J., 01

Bianco, V., OJ

Blacker, T. S., 01

Bora, llkay, 19

Borejdo, Julian, OF, 19

Börsch, Michael, 02, OB

Boutelle, Robert, 05

Bruschini, Claudio, 06

Burri, Samuel, 06

Charbon, Edoardo, 06

Choi, Seong Soo, 0

Deckers-Hebestreit, Gabriele, 02, OB

Dekker, Jan P., OA

Dienerowitz, Maria, 02

Doan, Hung, OF

Dubois-Delumeau, Maxime, 14

Duchen, M. R., 01

Fallet, Clement, $\mathrm{OH}, 14$

Ferraro, P., OJ

Fudala, Rafal, OF

Gao, Ying, OG

Gelfand, Martin P., OT

Glasgow, Ben J., 11

Goodwin, Peter M., OT

Gruber, J. Michael, OA

Gryczynski, Ignacy, OF, 19

Gryczynski, Zygmunt, OF, 19

Han, Chul Hee, Ol

Heitkamp, Thomas, 02, OB

Henkel, Thomas, 02

Hoebe, Ron, 06

Ilchenko, Mykhailo, 02

Ingargiola, Antonino, 05

Jin, Jingyi, OG

Killian, J. Antoinette, OA

Kim, Donghyun, 10

Kim, Sung In, Ol

Kim, Yong-Sang, 0 l

Kimball, Joe, OF

Lan, Li, OG

Lassalle, Astrid, 14

Laurence, Ted, 05

Laursen, Bo W., 19

Lee, Wonju, 10

Lindberg, Arvid, $\mathrm{OH}$

Liu, Yang, OG

Ma, Hongqiang, OG

Marchesano, V., OJ
Mayer, Günter, 02

Michalet, Xavier, 05

Park, Kyung Jin, Ol

Park, Myoung Jin, Ol

Park, Nam Kyou, Ol

Paturzo, M., OJ

Raut, Sangram L., OF, 19

Requena, Sebastian, OF, 19

Rich, Ryan, 19

Ryan, Duncan P., OT

Scheidelaar, Stefan, OA

Sheehan, Chris J., OT

Shtoyko, Tanya, 19

Sirat, Gabriel Y., OH, 14

Son, Taehwang, 10

Sørensen, Thomas Just, 19

Strzhemechny, Yuri, OF

Su, Bertram, 02

van Grondelle, Rienk, OA

Van Orden, Alan, OT

van Roon, Henny, OA

Weiss, Shimon, 05

Whitcomb, Kevin J., OT

$\mathrm{XU}$, Jianquan, $\mathrm{OG}$

Yoo, Jung $\mathrm{Ho}, \mathrm{Ol}$ 
Proc. of SPIE Vol. $971497141 \mathrm{G}-6$

Downloaded From: https://www.spiedigitallibrary.org/conference-proceedings-of-spie on 26 Apr 2023 Terms of Use: https://www.spiedigitallibrary.org/terms-of-use 


\title{
Conference Committee
}

\author{
Symposium Chairs
}

James G. Fujimoto, Massachusetts Institute of Technology

(United States)

R. Rox Anderson, Wellman Center for Photomedicine, Massachusetts General Hospital (United States) and Harvard School of Medicine (United States)

Program Track Chairs

Ammasi Periasamy, University of Virginia (United States)

Daniel L. Farkas, University of Southern California (United States) and Spectral Molecular Imaging, Inc. (United States)

Conference Chairs

Jörg Enderlein, Georg-August-Universität Göttingen (Germany) Ingo Gregor, Georg-August-Universität Göttingen (Germany)

Zygmunt Karol Gryczynski, University of North Texas Health Science Center (United States) and Texas Christian University (United States)

Rainer Erdmann, PicoQuant GmbH Berlin (Germany)

Felix Koberling, PicoQuant GmbH (Germany)

Conference Program Committee

Sohail Ahmed, A*STAR Institute of Medical Biology (Singapore)

Michael Börsch, Friedrich-Schiller-Universität Jena (Germany)

Christian Eggeling, University of Oxford (United Kingdom)

Paul M. W. French, Imperial College London (United Kingdom)

Ewa M. Goldys, Macquarie University (Australia)

Johan Hofkens, KU Leuven (Belgium)

Zhen-Li Huang, Huazhong University of Science and Technology (China)

Thomas R. Huser, Universität Bielefeld (Germany)

Maria Teresa Neves-Petersen, International Iberian Nanotechnology Laboratory (Portugal)

Markus Sauer, Universität Bielefeld (Germany)

Shimon Weiss, University of California, Los Angeles (United States)

Andong Xia, Institute of Chemistry (China) 
Proc. of SPIE Vol. $971497141 \mathrm{G}-8$

Downloaded From: https://www.spiedigitallibrary.org/conference-proceedings-of-spie on 26 Apr 2023 Terms of Use: https://www.spiedigitallibrary.org/terms-of-use 